\title{
KEEPING WOLFF FROM THE DOOR: CALIFORNIA'S DIMINISHED CAPACITY CONCEPT
}

In California a defendant may plead diminished capacity when, by reason of mental disease or defect not aniounting to insanity, or because of intoxication, he was unable to form any of the mental states essential to the crime charged. ${ }^{1}$ Thus a defendant accused of first degree inurder found not to have the required intent to kill due to diminished capacity can only be found guilty of manslaughter.

Since its inception in 1949, the diminished capacity defense in California has developed along two separate but equally important lines. One inain line of development can be terned the Conley approach. $^{2}$ This approach focuses on the various states of mind essential to one or both grades of murder-malice, premeditation, deliberation, and intent to kill-the presence of which, according to the Conley doctrine, can be refuted by evidence of any mental abnormality not amounting to insanity. The defendant's diminished capacity distorts the emotional and intellectual perceptions he has of his act and renders him incapable of performing as would a reasonable, mentally normal man. The Conley approach has gaimed official recognition in the diminished capacity instruction for Califorma courts. ${ }^{3}$

1. To date the three major articles on the California diminished capacity concept are: Kay, Diminished Capacity, 42 Calif. STATE Bar J. 385 (1967); Leib, Diminished Capacity: Its Potential Effect in California, 3 LoyolA L. REv. 153 (1970); Cooper, Diminished Capacity, 4 Loyola L. REv. 308 (1971). Kay takes a historical approach which, due to its early date of publication, unfortunately does not cover some major developments in the field of diminished capacity. Leib discusses diminished capacity as an alternative to the imsanity test and in terms of "status" diseases such as alcohohsm and drug addiction. He also suggests extension to include any "specific intent" crime. Cooper gives a good account of the historical development of the concept, but his analysis of the defense is limited in scope simce it was written for the benefit of the practitioner. He does, however, note briefly the several different lines of thought by which the supreme court has approached the problem.

Both Leib and Cooper agree, as does this writer, that there is no need to restrict the diminished capacity concept to crimes of inurder and manslaughter. The scope of the analysis of this Comment will, however, be himited to that field.

The diminished capacity defense has received only limited acceptance ontside California, although it has occasionally been advocated. See generally Annot., 22 A.L.R.3d 1228 (1968).

2. People v. Conley, 64 Cal. 2d 310, 411 P.2d 911, 49 Cal. Rptr. 815 (1966).

3. The California diminished capacity jury instruction states: Diminished Capacity-Ability to Premeditate, Deliberate, Harbor Malice, or Intend to Kill:

If you find froin the evidence that at the time the alleged crime was conmitted, the defendant had substantially reduced mental capacity, whether caused by niental illness, mental defect, intoxication, or any other cause, you 
The second line of development of diminished capacity began with People v. Wolff. ${ }^{4}$ The Wolff approach, in addition to considering the defendant's ability to form the mental states necessary to a crime, focuses on his ability to understand the moral and social values underlying the laws. The key phrase highlighting this trend is what the California Supreme Court has terned the issue of defendant's "moral turpitude."5 The defendant's diminished responsibility derives from his inability "to maturely and appreciatively reflect" upon his act and to realize the "enormity of the evil" imvolved. ${ }^{B}$ In short, the focus of Wolff is on the defendant's moral perceptions.

The Wolff doctrine, distinctive though it is, has not been formally recognized im Califorma as an independent jury instruction. Indeed, Wolff has, in general, not been fully acknowledged by the courts or appreciated by lawyers as a significant imdependent trend in diminished capacity. Rather, the novel features of the Wolff doctrine have been obscured by the California Supreme Court in an effort to annalgamate the two approaches to the diminished capacity defense.

Part I of this Comment traces the evolution of the diminished capacity concept. Part II analyzes the important differences between the Wolff and Conley doctrines; it also illustrates the growing dominance of the Conley approach and the corresponding decline of the Wolff approach. Part III suggests reasons for and methods of revitalizing the Wolff defense.

\section{I}

\section{The Evolution of the Dimtnished Capacity Defense}

In 1949 the California Supreme Court laid the foundation for the

must consider what effect, if any, this diminished capacity had on the defendant's ability to form any of the specific mental states that are essential elements of murder and voluntary manslaughter.

Thns, if you find that the defendant's mental capacity was diminished to the extent that you have a reasonable doubt whether he did, maturely and meaningfully, premeditate, deliberate, and reflect upon the gravity of his contemplated act, or form an intent to kill, you cannot find him guilty of a willful, deliberate and preneditated murder of the first degree.

Also, if you find that his mental capacity was diminshed to the extent that you have a reasonable doubt whether he did harbor malice aforethought, you cannot find him guilty of murder of either the first or second degree.

Furthermore, if you find that his mental capacity was diminished to the extent that he neither harbored malice aforethought nor had an intent to kill at the time the alleged crime was committed, you cannot find him guilty of either murder or volnntary manslaughter.

Committee on Standard Jury Instructions, Criminal, of the Superior Court of Los Angeles County, California, California Jury Instructions, Criminal 8.77 at 225 (3d rev. ed. 1970) [heremafter cited as CALJIC].

4. 61 Cal. 2d 795, 394 P.2d 959, 40 Cal. Rptr. 271 (1964).

5. Id. at 822, 394 P.2d at 976, 40 Cal. Rptr. at 288 .

6. Id. 
diminished capacity concept in People v. Wells. ${ }^{7}$ The Wells court reasoned that, like any other element of a crime, a specific inental state cannot be presumed but inust be proven. ${ }^{8}$ The court held that evidence of reduced mental capacity tending to show the absence of any mental state essential to the crime alleged should be accepted by the trial court. Thus, whether or not a plea of insanity is entered, evidence of any mental disease or defect must be considered by the trial court as relevant to the question of guilt. Although the court in Wells dealt specifically with the mental state of nlalice, it did not specify which inental states could be refuted by evidence of mental abnormality. ${ }^{9}$

A decade later, in People v. Gorshen, ${ }^{10}$ the court reiterated the general principle established by Wells, but it concentrated its analysis on the mental states of malice, premeditation, deliberation, and intent to kill, simce these were the essential elements of the crime chargedfirst degree murder. ${ }^{11}$ The Wells-Gorshen rule, ${ }^{12}$ however, follows the

7. 33 Cal. 2d 330, 202 P.2d 53 (1949).

8. Id. at 350,202 P.2d at 65 .

9. Wells was a prisoner who assaulted a guard while under an indefinite sentence, a crime that by statutory definition required inalice. At trial, Wells was not allowed to present expert testimony to show that he was in a state of high tension at the time of the crime, and that he had an abnormal fear for his personal safety. Such testimony, as the supreine court pointed out, could have established that Wells' fear was genuine and that he therefore lacked malice aforethought. Id. at 343-45, 202 P.2d at 61-63.

10. 51 Cal. $2 d 716,336$ P.2d 492 (1959). Gorshen claimed he heard voices, and the defense psychiatrist testified that the defendant suffered from chronic paranoiac schizophrenia and sexual hallucinations and was worried about his sexual prowess. He further indicated that defendant's work as a docker was, to Gorshen, a symbol of his virility. Defendant had been drinking, and was involved in a fight with his work supervisor, who had ordered him hoine for drunkenness. Gorshen went hoine but returned with a gun, saying that he "had to kill" his supervisor. He did so-in the presence of police officers.

11. Defendant was appealing a second degree inurder charge, but the court discussed both grades of murder, deciding that any charge of murder put into question the existence of all mental states essential to murder and manslaughter. The defendant must be allowed to show that he did not have the mental states necessary for the crime charged at the time of the crime. $51 \mathrm{Cal} .2 \mathrm{~d}$ at 733, $336 \mathrm{P} .2 \mathrm{~d}$ at 502 .

The trial court seemed confused on this point, although the supreme court held that there was no reversible error. The trial court had informally expressed its opinion that the defendant's threats and actions showed both intent to kill and malice, but that "whether he was compelled to do this because of some mental condition, that is so advanced . . . that we don't understand it." (sic) The supreme court chose to interpret this statement as meaning that the lower court did not have a reasonable doubt that Gorshen intended to kill and had malice when he acted. Id. at 735, 336 P.2d at 504. One suspects, however, that in fact the trial judge was unclear how much weight he should give the evidence presented and so compromised on a verdict of second degree murder.

12. CALJIC, supra note 3, 3.35, Diminished Capacity to Form Specific Mental State:

When a defendant is charged with a crime which requires that a certain 
principle established in Wells and does not enumerate the particular mental states that can be refuted by evidence of inental disease. In essence, that rule states: "A certain specific intent or mental state essential to constitute the crime" can be refuted by evidence of "abnormal mental or physical condition." ${ }^{13}$ Although it is quite likely that the court did not intend to create a diminislied capacity formula that limited the states of mind which could be refuted by evidence of mental disease, Gorshen in effect introduced sucli a formula.

The Gorshen court also held that voluntary intoxication was a form of diminished capacity that could negate malice and thereby reduce a charge of murder to manslaughter. This ruling marks a significant policy change: previously California courts had held that evidence of voluntary intoxication could be used only to reduce a first degree murder charge to second degree by showing an absence of "specific intent." "14

\section{A. People v. Conley: The First Formula is Finished}

With People v. Conley in $1966,{ }^{15}$ the California Supreme Court gave a naine and a structured form to the doctrine of diminished capacity begun in Wells and Gorshen. Premising its holding on the general principles of the Wells-Gorshen rule, the court in Conley ac-

specific intent or mental state be established in order to constitute the crime or degree of crime, you must take all the evidence into consideration and determine therefrom if, at the time when the crime allegedly was committed, the defendant was suffering from some abnormal mental or physical condition, however caused, which prevented him from forming the specific intent or mental state essential to constitute the crime or degree of crime with which he is charged.

If from all the evidence you have a reasonable doubt whether defendant was capable of forming such specific intent or mental state, you must give defendant the benefit of that doubt and find that he did not have such specific intent or mental state.

13. Id.

14. For a review of voluntary intoxication as a defense to a criminal charge, see generally Annot., 8 A.L.R.3d 1236 (1966).

15. 64 Cal. 2d 310, 411 P.2d 911, 49 Cal. Rptr. 815 (1966). Conley named the concept but important steps in the growth of diminished capacity had taken place before 1966. In People v. Modesto, 59 Cal. 2d 722, 382 P.2d 33, 31 Cal. Rptr. 225 (1963), the court beld that it was reversible error to fail to give manslaughter instructions if the defendant showed any sort of evidence purporting to refute malice. The defendant "has a constitutional right to have the jury determine every material issue presented by the evidence." Id. at 730, 382 P.2d at 38, 31 Cal. Rptr. at 230. In People v. Henderson, 60 Cal. 2d 482, 386 P.2d 677, 35 Cal. Rptr. 77 (1963), the court employed the term "diminished responsibility" to describe the Wells-Gorshen defense. The supreme court held that when a defendant rehies upon a "defense that ... he had no control over his actions because of his intoxication and illness not amounting to legal insanity" he must be allowed to present that evidence. In People v. Steele, 237 Cal. App. 2d 182, 46 Cal. Rptr. 704 (2d Dist. 1965), a district court of appeal noted that the Wells rule is equally applicable to mental states not considered in Wells. 
knowledged that evidence of diminished capacity, ${ }^{16}$ caused by either intoxication, trauma, or disease, can support a finding that the defendant did not have a specific mental state essential to the crime. ${ }^{17}$ The court, however, then proceeded to formulate a much more narrow standard, which conceived diminished capacity as a way of refuting four specific inental states: malice, premeditation, deliberation, and intent to kill. The model jury instruction the court suggested was to be given whenever the defendant presented evidence of diminished capacity. The instruction also created two new crimes that spring from the diminished capacity concept: non-statutory voluntary manslaughter and non-statutory imvoluntary manslaughter. ${ }^{18}$ Conley thus is a defense which can be used to show that some mental abnormality at the time of the crime severely affected the defendant's emotional or intellectual ability to have the states of mind that would justify a verdict of first or second degree inurder.

California courts, in a succession of cases since Conley, have clarified and repeated the model diminished capacity instruction. But, these post-Conley cases have not further developed the substance of the doctrine; rather, they have involved theinselves with technical details of the defense. ${ }^{19}$

16. This statement marks the first time that the term "diminished capacity" appears, although the decision gives the impression that the doctrine was permanent and well-established.

17. 64 Cal. $2 \mathrm{~d}$ at 316,411 P.2d at 914,49 Cal. Rptr. at 818.

18. The defendant has offered evidence that because of mental illness and intoxication he was unconscious. If you find that he was conscious of the shootings, but had substantially reduced mental capacity because of mental illness or intoxication, you must consider what effect, if any, this diminished capacity had on the defendant's ability to form any of the specific mental states that are essential elements of murder, which I have defined for you, or of manslaughter, which I will define shortly. . . .

[I]f you find that the defendant did not harbor malice, because of his diminshed capacity, or have a reasonable doubt whether he harbored malice, you cannot find him guilty of a higher offeuse than manslaughter.

Manslaughter is the unlawful killing of a human being without malice. Two kinds of manslaughter, the definitions of which are pertinent here, are:

1. Voluntary manslaughter, an intentional killing in which the law, recognizing human frailty, permits the defendant to establish the lack of malice either by

a. Showing provocation such as to rouse the reasonable man to heat of passion or sudden quarrel. . . . .

b. Showing that due to diminished capacity caused by mental illness, mental defect, or intoxication, the defendant did not attain the mental state constituting makice.

... [I]f you find that the defendant killed while unconscious as a result of voluntary intoxication and was therefore unable to formulate a specific intent to kill or to harbor malice, his killing is involuntary manslaughter. . . .

People v. Conley, 64 Cal. $2 \mathrm{~d}$ at 324-25, 411 P.2d at 920-21, 49 Cal. Rptr. at 824-25.

Thus, non-statutory volnntary manslaughter is the crime in which, because of dininished capacity, the defendant had no malice. Non-statutory involuntary manslaughter is the crime in which, because of diminished capacity, the defendant had neither intent to kill nor makice.

19. People v. Aubrey, 253 Cal. App. 2d 912, 61 Cal. Rptr. 772 (2d Dist. 1967) 


\section{B. People v. Wolff: The Second Formula Emerges}

In 1964, two years before Conley was decided, the second approach to the diminished capacity defense emerged in People $v$. Wolff. The court in Wolff faced the case of a schizophrenic fifteen-year-old boy who killed his mother with an axe handle so that he could bring girls home, anesthetize them, and then either rape them or photograph them nude. Wolff was found legally sane by the jury, since he had stated, and experts agreed, that he knew the difference between right and wrong. It was evident from testimony at the trial, however, that Wolff was not mentally well. ${ }^{20}$ The supreme court ruled that, although he had indeed premeditated and had intended to kill, the controlling issue was not simply the character of the killing but also the quantum of personal turpitude involved. ${ }^{21}$ A proper test, the court decided, must imclude an examination of the defendant's ability to "maturely and meaningfully reflect upon the gravity of his contemplated act."22 According to the court, Wolff was vague and detached; thus the "extent of his imderstanding," his reflection upon the act and its consequences, and his "realization of the enormity of the evil,"23 was extremely limited. His lack of comprehension was significant particularly as it related to the degree of moral turpitude and depravity necessary for the crime.

The court's language imphies that it was concerned with Wolff's understanding of the moral wrongness of murder. The court felt it was crucial that, in order to be found guilty of first degree murder, the defendant have the ability to understand the "evil" of his act and be able to realize why society condemned his act. This understanding of the moral wrongness of a crime is thus distinct from the Conley requirement that the defendant have the mental ability to form all the necessary mental states for murder.

The court based much of its argument on two previous cases:

endorsed the new definition of non-statutory voluntary manslaughter and held that instructions on the crime must be given whenever any evidence of diminished capacity is shown. People v. Mosher, 1 Cal. 3d 379, 461 P.2d 659, 82 Cal. Rptr. 379 (1969) added support to the new defimition of non-statutory involuntary manslaughter. Conley was sent back for a third trial when the trial judge failed to give an instruction on non-statutory manslaughter. 268 Cal. App. 2d 47, 73 Cal. Rptr. 673 (3rd Dist. 1968). People v. Rodriguez, 274 Cal. App. 2d 487, 79 Cal. Rptr. 187 (4th Dist. 1969), held that, when any evidence of diminished capacity is introduced, full instructions on diminished capacity (from murder through non-statutory involuntary manslaughter) must be given sua sponte.

20. 61 Cal. 795, 822, 394 P.2d 959, 976, 40 Cal. Rptr. 271, 288 (1964).

21. Id. at 823,394 P.2d at 976,40 Cal. Rptr. at 288.

22. Id. at 821, 394 P.2d at 975,40 Cal. Rptr. at 287.

23. Id. at 822,394 P.2d at 976,40 Cal. Rptr. at 288. 
People v. Holt ${ }^{24}$ and People v. Thomas ${ }^{25}$-cases that had articulated the distinction between first and second degree murder. In Holt, the court reasoned that the division of intentional homicides into murder and voluntary manslaughter and again of murder into two degrees is a recognition of the difference in the quantum of moral turpitude required for the various offenses. For a homicide to be labeled first degree rather than second degree murder, an appraisal involving more than simply the objective facts must be made. ${ }^{26}$ In Thomas, the court ruled that merely planning an act did not constitute deliberation because: (1) to deliberate means to "consider the reasons for and against; to consider maturely; reflect upon;"27 and (2) for first degree murder the law requires "substantially more reflection than may be involved in the mere formation of a specific intent to kill."28 Thus, the real test of deliberation is not the duration of reflection, but the extent of reflection by the defendant. ${ }^{29}$

The Wolff court used the Holt phrase-quantum of personal (or moral) turpitude - as a convemient expression of what it felt to be the "true test" of first degree murder. To convict a defendant of first degree murder, the defendant must be able to appreciate the moral implications of his act; he must have reflected maturely upon his actions. The court concluded that Wolff, because of his mental illness, could not understand the moral implications of his crime, and he thus lacked the measure of personal turpitude and depravity necessary for a first degree murder conviction.

Thus, Wolff added a second and crucial element to the classic formulation of deliberation and premeditation: in order to have truly premeditated, the defendant must not only have planned the murder, but also maturely reflected upon his act and been capable of understanding the moral considerations involved. If, due to mental illness, he could not premeditate or deliberate in this second sense, he could not commit the crime of first degree murder.

\section{II}

\section{WOLFF ENTERs AND ExITS}

At first the California Supreme Court found the Wolff logic extremely valuable and the Wolff and Conley lines of thought developed

24. 25 Cal. 2d 59, 153 P.2d 21 (1944).

25. 25 Cal. 2d 880, 156 P.2d 7 (1945).

26. 25 Cal. $2 \mathrm{~d}$ at $89-90,153$ P.2d at 37 .

27. 25 Cal. $2 \mathrm{~d}$ at 898,156 P.2d at 17 [quoting Webster's New Int. Dict. (2d ed.)].

28. Id. at $900,156 \mathrm{P} .2 \mathrm{~d}$ at 18 .

29. Id. 
separately for several years under the shelter of the new diminished capacity doctrine. In the last few years, however, the supreme court has been reluctant to recognize Wolff as an independent doctrime. Instead, it has atteinpted to weave the two separate threads into a single diminished capacity pattern. The result has been a significant weakening and distortion of the Wolff approach: the Wolff doctrine is in danger of becoming simply another way of stating some of the Conley criteria.

\section{A. Wolff Comes Alive}

In three cases following Wolff, the supreme court entirely disregarded the Conley approach-even though it had been applied correctly in the trial courts-and invoked the Wolff rationale in order to reduce first degree inurder sentences to second degree. ${ }^{30}$ People $v$. Goedecke, ${ }^{31}$ People v. Nicolaus, ${ }^{32}$ and People v. Bassett ${ }^{33}$ were factually shocking cases. Goedecke brutally, and with great care, murdered his entire family without a sign of remorse,;4 Nicolaus killed his three children to save them froin an "intolerable" environment; ${ }^{35}$ Bassett "methodically executed"36 his parents. After hearing the facts of each case, an outsider might easily exclaim: "The man must have been inad!" Although the three defendants had been found legally sane, the supreme court did not feel it could in good conscience allow the first degree inurder verdicts to stand. So shocking were the three cases, it seemed that the defendants could not possibly have understood the moral significance of what they had done. The supreme court found each defendant to be suffering from a mental defect that rendered him so emotionally detached and morally blind that he was unable truly to premeditate his crime. ${ }^{37}$

In Goedecke and Nicolaus there had been extensive testimony on the defendants' ability to premeditate and deliberate, at least in the sense of their ability to plan the act (the Conley formula). The court ignored all such testimony, however, and invoked the Wolff doctrine,

30. The supreme court has never reversed a conviction or changed a sentence in the Conley line of cases; it has simply sent these cases back for retrial with firm instructions that, on any showing of diminished capacity, full dimimished capacity (Conley) instructions should be given.

31. 65 Cal. 2d 850, 423 P.2d 777, 56 Cal. Rptr. 625 (1967).

32. 65 Cal. 2d 866, 423 P.2d 787, 56 Cal. Rptr. 635 (1967).

33. 69 Cal. 2d 122, 443 P.2d 777, 70 Cal. Rptr. 193 (1968).

34. $65 \mathrm{Cal} .2 \mathrm{~d}$ at 854,423 P.2d at 780, $56 \mathrm{Cal}$. Rptr. at 628.

35. In order to save them from their "environments which he considered intolerable . . . he decided he would bring the children to a state of extreme happiness and kill them . . ." 65 Cal. 2d at 873, 423 P.2d at 792, 56 Cal. Rptr. at 640 .

36. $69 \mathrm{Cal} .2 \mathrm{~d}$ at 124, 443 P.2d at 778, $70 \mathrm{Cal}$. Rptr. at 194.

37. See, e.g., People v. Goedecke, 65 Cal. $2 \mathrm{~d}$ at 857, 423 P.2d at 782,56 Cal. Rptr. at 630. 
rather than restricting itself to the Conley formula. ${ }^{38}$ The court in Bassett found inconclusive the testimony by prosecution witnesses that defendant had maturely and meaningfully premeditated since the prosecution had obscured the significance of the Wolff approach to diminished capacity by its ritualistic use of the correct Wolff words. According to the court, this testimony did not actually consider defendant's moral awareness of his crime. Defense witnesses, however, did present specific evidence on the issue of whether or not "defendant [had] the mental capacity to weigh and consider the reasons for and against killing his parents." 39 The supreme court therefore concluded that the evidence could only support a verdict of second degree inurder.

The instinctive reaction to these cases is that they were correctly decided under the Wolff part of the diminished capacity concept. The court in each case merely had to use Wolff language to convince itself and its audience that Bassett, Nicolaus, and Goedecke were indeed people like Wolff--inentally abnormal, lacking a full understanding of the significance of their crimes. ${ }^{40}$ Each case evokes the upsetting feeling that the defendant coinpletely lacked any inoral capacity, and indeed, that he had inost of the inarks of insanity. ${ }^{41}$ Yet the present California insanity test allows only one criterion: did the defendant know that what he did was wrong? In these diminished capacity cases each defendant, imcluding Wolff, could state the difference be-

38. The supreme court stated that, although both prosecution psychiatrists believed that defendant could and did deliberate and premeditate his act, neither expressed an opinion about the extent of defendant's ability to "maturely and meaningfully reflect upon the gravity of his contemplated act." 65 Cal. $2 \mathrm{~d}$ at 878, 423 P.2d at $795,56 \mathrm{Cal}$. Rptr. at 643 . The court held that, even though there was a conflict in regard to defendant's ability to form an intent to kill and to preineditate the killing, no psychiatric testimony was presented as to the extent to which defendant could meaningfully reflect upon the gravity of that killing. Thus, when the trier of fact decided that defendant did have the mental capacity to form the intent to kill, the supreme court held that it could still ask whether "in a perplexing murder of this kind" the evidence was sufficient to bring in a verdict of first degree murder. Id. at 857,423 P.2d at 872, 56 Cal. Rptr. at 630 .

39. 69 Cal. $2 \mathrm{~d}$ at 128-37, 141-48, 443 P.2d at 781-86, 788-94, 70 Cal. Rptr. at 197-202, 204-10.

40. The Goedecke court quoted a long passage from Wolff which contained all the essential Wolff terms and concepts. 65 Cal. $2 \mathrm{~d}$ at 855-56, 423 P.2d at 777, 56 Cal. Rptr. at 629 . The same paragraph is used in the Nicolaus opinion. 65 Cal. 2d at 877-78, 423 P.2d at 795, 56 Cal. Rptr. at 643.

41. Interestingly, the court specifically referred to all three Wolff cases as "bizarre". For example, the Goedecke court refers to "the bizarre nature of the killing," 65 Cal. $2 \mathrm{~d}$ at 857, 423 P.2d at 782, 56 Cal. Rptr. at 630. The terin is not applied to any of the Conley cases and is later used by the court to distinguisl Wolff-type cases. The use of the term seems, simply, a further indication of the court's belief that what Bassett, Nicolaus and Goedecke did was so beyond the pale of normal societal values that it was evident that the three men suffered serious mental abnornalities, even though not legally insane. 
tween right and wrong, but their statements lacked emotion, understanding, or meaning.

Cases where the defendant is not clearly imsane by the rightwrong test, yet is mentally ill, are difficult to handle from the standpoint of assessing criminal responsibility. This should not, however, justify denying a jury the opportunity to consider evidence of mental illness as it affects the defendant's understanding of the moral wrongness of his act. If members of the jury, as impartial outsiders, see no evidence of mental disease in a defendant who commits a crime such as Goedecke or Wolff committed, then they should and must find the defendant guilty of first degree murder. There will, however, undoubtedly be cases where the jury will have a strong feeling that the defendant, as the result of mental defect, cannot be held fully responsible for his crime and that it simply is not proper to punish him as severely for his actions as a mentally healthy person. There is sufficient understanding of the problems of mental illness that a jury should be able to temper its condemnation of the defendant imcapable of really understanding the moral evil of his act. In Wolff, Bassett, Goedecke, and Nicolaus the supreme court acted as the judge of defendant's moral capacity, however, and displaced this jury function.

\section{B. Wolff Is Forced to Retreat}

Recently, when faced with less clear-cut cases, the supreme court has avoided applying Wolff and, in rationalizing its avoidance, has imcreasingly obscured the doctrine.

The retreat began with People v. Risenhoover, ${ }^{42}$ which affirmed a conviction of first degree inurder, even though the defendant had previously been committed as insane. The court first held that the defendant had malice and substantiated this conclusion by citing certain passages in Goedecke and Nicolaus. But none of the passages cited by the court in Risenhoover deal with malice; rather they are discussions of Wolff, which dealt only with premeditation and deliberation. Thus there is no support for the court's assertion in Risenhoover that the defendant had malice. The court simply stated its conclusion, and there let the inatter rest.

After holding that the defendant had inalice, the Risenhoover court discussed wilful, deliberate, and premeditated murder. Quoting Wolff, the court concluded that the defendant had ample time to reflect on the killing, was able to premeditate and deliberate, and that evidence

42. 70 Cal. 2d 30, 447 P.2d 925, 73 Cal. Rptr. 533 (1968). Defendant kidnapped a boy and girl in their car and later shot and killed the boy. None of his actions had an apparent motive. Defendant had a history of mental illness. 
that he had been committed as insane did not preclude a finding that he maturely and meaningfully reflected upon the gravity of the crime. ${ }^{43}$ The court's reasoning confused several major issues. As Wolff made clear, the amount of time a defendant reflects upon his crime is not a vital consideration. It is, as the court has repeatedly said, the extent of the reflection that is crucial. The holding in Wolff was that, in order to establish that the defendant fully premeditated and deliberated, there must be evidence of his appreciation of the moral implications of his act-im addition to evidence of careful planning. The court in Risenhoover implicitly concluded, however, that the ability to premeditate and deliberate in the traditional sense-planning one's actions carefully-is sufficient evidence of mature reflection on those actions. The inevitable result of the Risenhoover holding will be confusion in the lower courts which will conclude that, if there is evidence that a defendant planned his acts and had time to reflect, then he must have inaturely and meaningfully reflected on and understood the moral evil of his crime.

\section{The Abandonment of Wolff}

The California Supreine Court undoubtedly realized that it was not the appropriate body to act as judge of the defendant's moral capacity. The jury, which represents the conscience of the community and the general standard of morality, ${ }^{44}$ is the proper body to make a judgment determining the defendant's ability to appreciate the moral evil of his act. Because that is the jury role and because assessinents of moral capabilities are very hard to make, the supreme court probably felt compelled to stop invoking Wolff in order to reduce convictions for mentally disturbed defendants.

The confusion caused by the supreme court's apparent ambivalence toward the Wolff doctrine forced the court to reach a decision concerning the status of the Wolff approach to diminished capacity. There were at least two solutions to the problem at this point: (1) a reaffirmation of the validity of the Wolff doctrine and a ruling that explicit and meaningful Wolff instructions must be given the jury in every case in which a diminished capacity defense has becn raised; or (2) a de-emphasis of Wolff as a standard of diminisled capacity imdependent of Conley and a merger of the two into a less subjective test. In In re Kemp ${ }^{45}$ the court finally took the second path. Kemp had

43. Id. at 52-53, 447 P.2d at 932-33, 73 Cal. Rptr. at 541-42.

44. The court held in People v. Holt that the appraisal of that "something more" necessary for first degree inurder was "primarily a jury function and within a wide field of discretion its determination is final." 25 Cal. 2d 59, 90, 153 P.2d 21, 37 (1944).

45. 1 Cal. 3d 190, 460 P.2d 481, 81 Cal. Rptr. 609 (1969). 
raped and killed a nurse; two years later he raped two other women. Testimony had shown that he had premeditated and had imtended to kill his victim. The defendant attempted to rely on Wolff and argued that due to a mental defect he lacked the ability to judge his actions. The supreme court responded that Wolff and the cases following it did not establish a new standard of diminished capacity. Instead, Wolff merely held that a determination of premeditation requires an appraisal of something more than objective facts. ${ }^{46}$ According to Kemp, the test in Wolff is nothing more than a restatement of the concepts of premeditation developed in People v. Thomas and People v. Holt. ${ }^{47}$

In any case, the court's attenpt to reconcile Kemp with the "Wolff" cases is substantially unsuccessful. In those cases the court used Wolff as a separate and crucial part of the element of premeditation, independent of the process of inerely planning an act. Unquestionably, Wolff derives from Holt and Thomas, but, as shown above, ${ }^{48}$ the language of Holt and Thomas clearly indicates that deliberation and . premeditation are imcoinplete without an ability to consider maturely and fully the significance of a criminal act. The "quantum of personal turpitude" which Holt considered the essential distinction between the various degrees of homicide became in Wolff an unportant, indeed final, determinant of whether or not the defendant was guilty of first degree murder. The court seriously compromised the imdependence of this concept when it labeled it an appraisal of something more than the objective facts.

The most recent case in which the supreme court has been faced with the Wolff defense is People v. Sirhan. ${ }^{40}$ In Sirhan, the court again dealt summarily with the Wolff principle and, by doing so, continued to obscure the essence of the concept.

Sirhan had pleaded that, due to diminished capacity, he was unable to premeditate and deliberate the assassination of Senator Robert Kennedy. The court first stated that People $v$. Wolff elucidated the meaning of deliberation and premeditation. ${ }^{50}$ It then cited a few of the most important passages in Wolff and Holt; those passages emphasized that the amount of time used for preneditation is irrelevant to a defendant's ability to understand the enormity of the evil of his act,

46. What could this "something more" be? In light of previous discussion, it should be an analysis of defendant's ability to understand what he has done, of his capacity to act after mature reflection. This is what the Wolff court was looking at and what it felt to be an essential part of the element of premeditation and deliberation.

47. 1 Cal. 3d at 194, 460 P.2d at 483, 81 Cal. Rptr. at 611.

48. See text accompanying notes 24-29 supra.

49. 7 Cal. 3d 710, 497 P.2d 1121, 102 Cal. Rptr. 385 (1972).

50. Id. at 727, 497 P.2d 1132, 102 Cal. Rptr. at 396. 
and that a defendant, $i m$ order to be guilty of first degree murder, must have shown the proper degree of moral turpitude. Yet, immediately following these crucial quotations, the court declared that Sirhan had had "ample time to reflect upon the killing,"51 and that, because defendant's actions were well-planned and defendant seemed "highly alert and intelligent" ${ }^{\prime 2}$ shortly after the murder, there was sufficient evidence from which to conclude that Sirhan had reflected maturely and meaningfully on his crime. ${ }^{53}$ But the ability to devise and skillfully execute plans is not evidence of a defendant's ability to understand the evil of those plans. Neither ample time nor clever execution prove the depravity or moral turpitude necessary for first degree murder. Thus the court in Sirhan has again lost the essence of Wolff..$^{54}$

III

\section{SUGGESTIONS FOR THE REVITALIZATION OF WOLFF}

The supreme court has become increasingly aware of the difficulties of its use of the Wolff defense to reduce a conviction, and the Wolff defense has becoine increasingly confused. However, Wolff should not be abandoned. The supreme court need not set itself up as judge of a defendant's moral capabilities, so long as it ensures that when men like Goedecke or Wolff come to trial the Wolff defense is fully available to them and is understood by the jury. Unquestionably, a mental defect can deprive a defendant of an accurate view of the morality of his acts. He may be able to think and skillfully plan a crime but may act for such peculiar reasons that the jury would be convinced he did not comprehend the evil of his actions. In such a case the Wolff defense is valuable, indeed essential, for fixing a punishment in accord with traditional principles of criminal responsibility.

Presently it is mandatory for a trial judge to give full instructions sua sponte on the inanner in which diminished capacity can refute the elements of intent, premeditation, deliberation and malice, and on nonstatutory manslaughter. In order to ensure the vitality of the Wolff defense, whenever diminished capacity instructions are given to a jury

51. Id. at 728, 497 P.2d 1132, 102 Cal. Rptr. at 396.

52. Id.

53. See text accompanying notes 26,27 , and 38 supra for an analysis of the illogical junp from finding that a defendant has planned a murder cleverly to concluding that he thus understood the moral aspects of that killing.

54. It may indeed be true that, in this case, Sirhan did not lack the capacity to appreciate the evil of his acts; that point is not at issue here. (There was conflicting evidence on this issue, however.) The crucial point here is that the supreme court has coutinued to nisinterpret and misuse the Wolff concept which it created eight years ago. 
the principles of the Wolff doctrine should be explained with the same thoroughness with which the Conley doctrine is now explained.

The diminished capacity instruction now used in California ${ }^{\text {t5 }}$ reflects the supreme court's perhaps unintentional success in obscuring the Wolff doctrine and is consequently inadequate for the task. The nnodel instructions from Conley are set forth in abbreviated form in the instructions, yet there is only a single reference to the Wolff test. ${ }^{\text {bi }}$ That reference-_"whether he did ... maturely and meaningfully ... reflect upon the gravity of his contemplated act" ${ }^{37}$ - of all the Wolff phrases least strongly suggests the issue of defendant's moral perceptions. Whether the defendant recognized the "evil" of the act and the defendant's "depravity" are much more effective ways of characterizing the issue of the defendant's morality. Only a very sensitive juror on hearing the present instruction would realize that he could consider the defendant's moral responsibility for the act and his awareness of the evil of its commission.

It may be difficult to define the Wolff criteria succinctly, particularly since it inust be kept separate froin the insanity issue. Yet if the jury instructions were to include all key Wolff language, and not inerely a single phrase, the jury would surely get a better sense of this essential element of premeditation and deliberation. A model instruction might read as follows:

"If you find from the evidence that at the time the alleged crime was committed, the defendant had substantially reduced mental capacity, whether caused by inental illness, inental defect, intoxication, or any other cause, you must consider what effect, if any, this diminished capacity had on the defendant's ability to form any of the specific inental states that are essential elements of first degree murder.

"Thus, if you find that the defendant's inental capacity was diminished to the extent that, regardless of the amount of time defendant

55. Several lower court cases also mirror a similar conceptual confusion, although the confusion is probably unintentional. See, e.g., People v. McQuiston, 12 Cal. App. 3d 584, 90 Cal. Rptr. 687 (3d Dist. 1970) and People v. Caylor, 259 Cal. App. 2d 191, 66 Cal. Rptr. 448 (2d Dist. 1968).

56. See note 3 supra for full text of CALJIC 8.77. The original language in Conley did hint briefly at the problem of the defendant's view of morality. The Conley court stated that part of the statutory definition of implied malice is an aware. ness of the "obligation to act within the general body of laws regulating society . . . ." If a defendant is unable to "comprehend his duty to govern his actions in accord with the duty imposed by law," then, by definition, he cannot be guilty of first degree murder. $64 \mathrm{Cal}$. $2 \mathrm{~d}$ at $322,411 \mathrm{P} .2 \mathrm{~d}$ at $918,49 \mathrm{Cal}$. Rptr. at 822. This language by the court implies that the defendant must have a moral awareness. However, the court does not develop further this facet of the Conley case m any of the later cases. As a result, none of this language appears in CAIJIC 8.77.

57. CALJIC, supra note $3,8.77$. 
devoted to planning his act, you have a reasonable doubt whether he was able to appreciate the moral evil of his act, or was able to realize the enormity of the evil of his act, or was a depraved human being, or whether he could maturely and meaningfully premeditate and deliberate on the moral significance of his act, you cannot find him guilty of a wilful, deliberate and premeditated murder in the first degree."

As the situation now stands, the supreine court has substantially obscured the Wolff defense and undercut one of the most significant steps in criminal law which it has taken in the past few decades. Independent jury instructions would reaffirm the validity of the Wolff doctrine. 